\title{
Effect of foliar fertilization with zinc and manganese sulfate on yield, dry matter accumulation, and zinc and manganese contents in leaf and seed of chickpea (Cicer arietinum)
}

\author{
Soheil Kobraee* \\ Department of Agronomy and Plant Breeding, Kermanshah Branch, Islamic Azad University, Kermanshah, Iran
}

\begin{tabular}{|c|c|}
\hline ARTICLE INFO & ABSTRACT \\
\hline $\begin{array}{l}\text { Article history: } \\
\text { Received on: August 16, } 2018 \\
\text { Accepted on: September 27, } 2018 \\
\text { Available online: April } 05,2019\end{array}$ & $\begin{array}{l}\text { To investigate the effects of zinc }(\mathrm{Zn}) \text { and manganese }(\mathrm{Mn}) \text { foliar fertilization on yield, dry matter accumulation, } \\
\mathrm{Zn} \text { and } \mathrm{Mn} \text { concentrations in leaf and seed of chickpea cultivars, a field experiment was conducted in 2014. The } \\
\text { experimental design was a split plot in randomized complete block with three replications. The phenological stages } \\
\text { recorded were as follows: Emergence, flowering, } 50 \% \text { flowering, and harvest maturity. At harvest, economic yield }\end{array}$ \\
\hline $\begin{array}{l}\text { Key words: } \\
\text { Atomic absorption spectrometry, } \\
\text { Chickpea, } \\
\text { Foliar fertilization, } \\
\text { Phenological stages, } \\
\text { protein }\end{array}$ & $\begin{array}{l}\text { and its components, biological yield, harvest index, stem, leaf, pod, seed, and total dry weight were measured. The } \\
\mathrm{Zn} \text { and Mn contents were determined by atomic absorption spectrometry. The results indicated that the spraying of } \\
\mathrm{Zn} \text { and Mn elements did not have a significant effect on the time from emergence to } 50 \% \text { flowering and the time } \\
\text { from emergence to maturation. Spraying treatments had a significant effect on dry weight of stems, leaves, pods, } \\
\text { seeds, and total plant. In all three cultivars, Zn spraying had the greatest effect on the plant height, number of pods per } \\
\text { plant, number of seeds per plant, 100-seed weight, grain yield, biological yield, and dry weight of leaves, seeds, and } \\
\text { total plant, while Mn spraying had the greatest effect on the increase in stem and pod dry weight and protein content. }\end{array}$ \\
\hline
\end{tabular}

\section{INTRODUCTION}

Chickpea (Cicer arietinum) is one of the most important food legume crops which is grown as a source of cheap protein for human. Chickpea contains $13-33 \%$ protein, $40-55 \%$ carbohydrate, $4-10 \%$ oil (50\% oleic and $40 \%$ linoleic acid) [1], B-group vitamins (thiamin, riboflavin, and niacin) [2], folate, $\beta$-carotene, and mineral elements such as $\mathrm{Zn}, \mathrm{Se}, \mathrm{Fe}, \mathrm{Ca}, \mathrm{Mg}, \mathrm{K}, \mathrm{Cu}$, and $\mathrm{P}$ [3]. In Iran, chickpea is cultivated on an area of 433,356 hectares with an annual seed production of 177,493 tones and average seed yield of $409.6 \mathrm{~kg} / \mathrm{ha}$ [4]. In our country, productivity of chickpea is still low and unstable due to its cultivation on marginal soils, especially under rainfed conditions. Nutrient management is one of the important factors for increasing its productivity. Recently, more attention has been paid to the application of microelement fertilizers. In calcareous soils, zinc (Zn) and manganese (Mn) deficiency are common $[5,6]$, and root availability to these elements is reduced [7]. Soils in many arid and semi-arid regions of Iran due to high $\mathrm{pH}$ and low organic matter are faced with $\mathrm{Zn}$ and $\mathrm{Mn}$ deficiencies. Soil application is a more common method to supply macronutrients to plants, but this

*Corresponding Author:

Soheil Kobraee,

Department of Agronomy and Plant Breeding,

Kermanshah Branch, Islamic Azad University,

Kermanshah, Iran. Tel.: 009887243181.

E-mail: Kobraee@yahoo.com approach will create problems for micronutrients [8], thus, in these soils, foliar application is more effective [9]. On the other hand, when root activity is reduced due to water deficit, foliar fertilization is more advantageous in absorption compared to soil application. According to Heidarian et al., and Narimani et al. [10,11] studies under drought stress, plant roots cannot absorb micronutrients, and foliar spraying of micronutrients will be useful. In brief, the main objectives of this study were to investigate changes in $\mathrm{Zn}$ and Mn concentrations in leaves and seeds, dry matter production, and yield and yield components of chickpea, after $\mathrm{Zn}$ and $\mathrm{Mn}$ foliar fertilization.

\section{MATERIALS AND METHODS}

\subsection{Site Description and Soil Analysis}

A field experiment was conducted on a research field of the Islamic Azad University of Kermanshah Province, Iran (34 $23^{\prime} \mathrm{N}, 47^{\circ} 8^{\prime} \mathrm{E} ; 1351 \mathrm{~m}$ elevation) in 2014 . The soil type of the experimental areas is silty clay with cold and rainy winters and hot and dry summers, and annual average precipitation is $478 \mathrm{~mm}$ before planting, soil samples were collected from an experimental area at a depth of $0 \mathrm{~cm}-30 \mathrm{~cm}$ for soil analysis. The texture of the soil corresponded to silty clay. The soil had the following properties: $\mathrm{pH} 7.1$, total organic matter $1.8 \%$, electrical conductivity $0.48 \mathrm{ds} / \mathrm{m}$, total nitrogen $0.15 \%$, available phosphorus $9.5 \mathrm{mg} / \mathrm{kg}$, available potassium $346 \mathrm{mg} / \mathrm{kg}$, and $\mathrm{Zn} 0.42$ and Mn $1.6 \mathrm{mg} / \mathrm{kg}$ soil. 


\subsection{Treatment and Experimental Design}

The experimental design was a split plot in randomized complete block with three replications. The main plot includes three cultivars: $\mathrm{C}_{1}=$ Flip 90-96C, $\mathrm{C}_{2}=$ Flip 93-93C , and $\mathrm{C}_{3}=$ Flip 84-48C; and three foliar fertilization which consisted of $\left(\mathrm{F}_{0}\right)$ spray with distilled water (control treatment), $\left(\mathrm{F}_{\mathrm{Zn}}\right) \mathrm{Zn}$ spray from $\mathrm{ZnSO}_{4}$ source, and $\left(\mathrm{F}_{\mathrm{Mn}}\right) \mathrm{Mn}$ spray from $\mathrm{MnSO}_{4}$ source which are replaced in subplot. A common dose of $50 \mathrm{~kg} \mathrm{P}_{2} \mathrm{O}_{5} /$ ha and $30 \mathrm{~kg} \mathrm{~N} /$ ha was applied to all plots as basal dose at the time of sowing. Before planting, seeds were presoaked in $10 \%$ sugar solution and then inoculated with Bradyrhizobium leguminosarum ( $2 \mathrm{~g} / \mathrm{kg}$ of seeds). The crop was sown on March 14, 2014. The experiment included nine treatments placed on 27 plots. The plots consisted of eight rows; $4 \mathrm{~m}$ in length and sand spaced at $25 \mathrm{~cm}$. The distance between plants in a row was $5 \mathrm{~cm}$ and the plant density was 800,000 plants/ha. Plots were hand weeded 2 times when needed. At the late of vegetative growth stage and/or before flowering, the plants were sprayed twice (with 1-week interval) with $0.5 \%(w / v)$ or distilled water until the leaves were wet based on [12] the study.

\subsection{Plant Sampling}

The phenological development of the crop was monitored at 2-3day intervals for all seasons from the onset of flowering. The phenological stages recorded were as follows: Emergence (E), flowering $(\mathrm{F}), 50 \%$ flowering $\left(\mathrm{F}_{50}\right)$, and harvest maturity $(\mathrm{HM})$. When $50 \%$ of the plants in any plot had emerged or had at least one open flower, or $50 \%$ of the plants in any plot had flowered, then this was designated as emergence, flowering, and 50\% flowering stage, respectively. HM was reached when $>95 \%$ of the plants in the plot had completely senesced and turned brown. At harvest, plant height, number of subbranch, pod and seed per plant, and 100-seed weight were measured on 10 randomly selected plants in each subplot. Furthermore, for measuring of stem, leaf, pod, seed, and total dry weight, the samples were dried at $70^{\circ} \mathrm{C}$ for $48 \mathrm{~h} .1 \mathrm{~m}^{2}$ from each sub-plot was harvested and blended and seed and biological yields $\left(\mathrm{g} \mathrm{m}^{-2}\right)$ were weighed. Harvest index (\%) was obtained by dividing economic yield by biological yield multiplied by 100 . To measure leaf and seed concentrations of micronutrients, $10 \mathrm{~g}$ of each leaf and seed sample were collected from the plots of each treatment. Samples (leaves and seeds, separately) were washed with distilled water, dried in an oven at $70^{\circ} \mathrm{C}$ for $48 \mathrm{~h}$, weighed, and incinerated at $550^{\circ} \mathrm{C}$. Dry ash samples were solved in concentrated $\mathrm{HNO}_{3}$ and $\mathrm{HClO}_{4}$. The $\mathrm{Zn}$ and $\mathrm{Mn}$ contents were determined by atomic absorption spectrometry according to Kacar [13]. Nitrogen measurements for total $\mathrm{N}$ were based on the Kjeldahl method. The Kjeldahl method was performed according to AOAC international [14].

\subsection{Statistical Analyses}

All the data obtained from the measurements were evaluated statistically with MSTATC software. Analysis of variance was performed after the Bartlett test for checking uniformity of data variance $(P=0.05)$. Least significant difference test was used to compare the means. Excel software was used to plot diagrams.

\section{RESULTS AND DISCUSSION}

\subsection{Effect of Cultivar and Foliar Treatments on $\mathrm{TF}_{50}$ and THM and Dry Weight Accumulation in Different Parts of Chickpea Plants}

The results of analysis of variance performed to test the effect of foliar fertilization with $\mathrm{Zn}$ and $\mathrm{Mn}$ sulfate on dry matter accumulation in different parts of chickpea plant shown in Table 1, indicated that there were significant differences between cultivars in terms of total dry weight $(P<0.05)$ and days from emerging $(\mathrm{E})$ to $\mathrm{HM}$ (THM) $(P<0.01)$. The days from emerging to HM ranged from 96 to 112 days, and Flip 93-93C was the earliest in reaching HM (112.61 days) compared to Flip 84-48C (99.13 days) and Flip 90-96C (96.12 days) cultivars. However, Flip 84-48C cultivar had shorter period of duration from emerging to $50 \%$ flowering (46 days). These results were consistent with the results obtained by Sabaghnia and Janmohammadi [15]. Based on Pearson correlation [Table 2], there was no significant correlation between chickpea growth period and spraying of $\mathrm{Zn}$ and $\mathrm{Mn}$. In fact, the spraying of $\mathrm{Zn}$ and Mn elements did not have a significant effect on the time from emergence to $50 \%$ flowering (TF50) and the time from emergence to maturation (THM). These results were somewhat different from those obtained by Janmohammadi et al. [16]. In their research entitled, "the impacts of nanostructured nutrients on chickpea performance under supplemental irrigation," the application of $\mathrm{Zn}$ and $\mathrm{Mn}$ on the number of days from emergence to $50 \%$ flowering had a very significant effect, such that $\mathrm{Zn}$ consumption in comparison with other treatments has reduced the duration of up to $50 \%$ flowering in chickpea. Spraying treatments had a significant effect on dry weight of stems, leaves, pods, seeds, and total plant $(P<0.01)$. In contrast, dry weight of stems, leaves, pods, seeds, and total plant was not affected by interaction effects between cultivars and foliar $\times$ cultivar treatments [Table 1]. The

Table 1: Analysis of variance for the impact of $\mathrm{Zn}$ and $\mathrm{Mn}$ sulfate on dry matter accumulation in different parts of chickpea plant and times for emergence to $50 \%$ flowering and harvest maturity

\begin{tabular}{|c|c|c|c|c|c|c|c|c|}
\hline \multirow[t]{3}{*}{ SOV } & \multirow[t]{3}{*}{ df } & \multicolumn{7}{|c|}{ Ms } \\
\hline & & \multicolumn{5}{|c|}{ Dry weight of } & \multicolumn{2}{|c|}{ Days after sowing } \\
\hline & & Stem & Leaf & Pod & Seed & Total plant & TF50 & THM \\
\hline Cultivar (C) & 2 & $0.427^{\mathrm{ns}}$ & $1.002^{\mathrm{ns}}$ & $0.128^{\mathrm{ns}}$ & $0.120^{\text {ns }}$ & $13.388^{*}$ & $50.500^{\mathrm{ns}}$ & $690.145^{* *}$ \\
\hline Error a & 4 & 0.308 & 0.227 & 0.921 & 0.096 & 1.445 & 10.983 & 35.909 \\
\hline Foliar treatment $(\mathrm{F})$ & 2 & $5.176^{* *}$ & $5.675^{* *}$ & $8.019 * *$ & $26.095 * *$ & $106.019 * *$ & $46.359^{\text {ns }}$ & $3.322_{\mathrm{ns}}$ \\
\hline Error b & 12 & 0.074 & 0.320 & 0.611 & 0.251 & 3.209 & 9.026 & 16.256 \\
\hline Coefficient of variation (\%) & - & 6.69 & 9.08 & 18.78 & 8.66 & 10.28 & 6.21 & 5.99 \\
\hline
\end{tabular}

$\mathrm{Ns}^{*}$ and $* *$ : Non-significant, significant at $5 \%$ and $1 \%$ levels of probability, respectively. TF50: Time to $50 \%$ flowering, THM: Time to harvest maturity, SOV: Source of variation, Zn: Zinc, Mn: Manganese 
Table 2: The effect of $\mathrm{Zn}$ and $\mathrm{Mn}$ sulfate on dry matter accumulation in different parts of chickpea plant and times for emergence to $50 \%$ flowering and harvest maturity

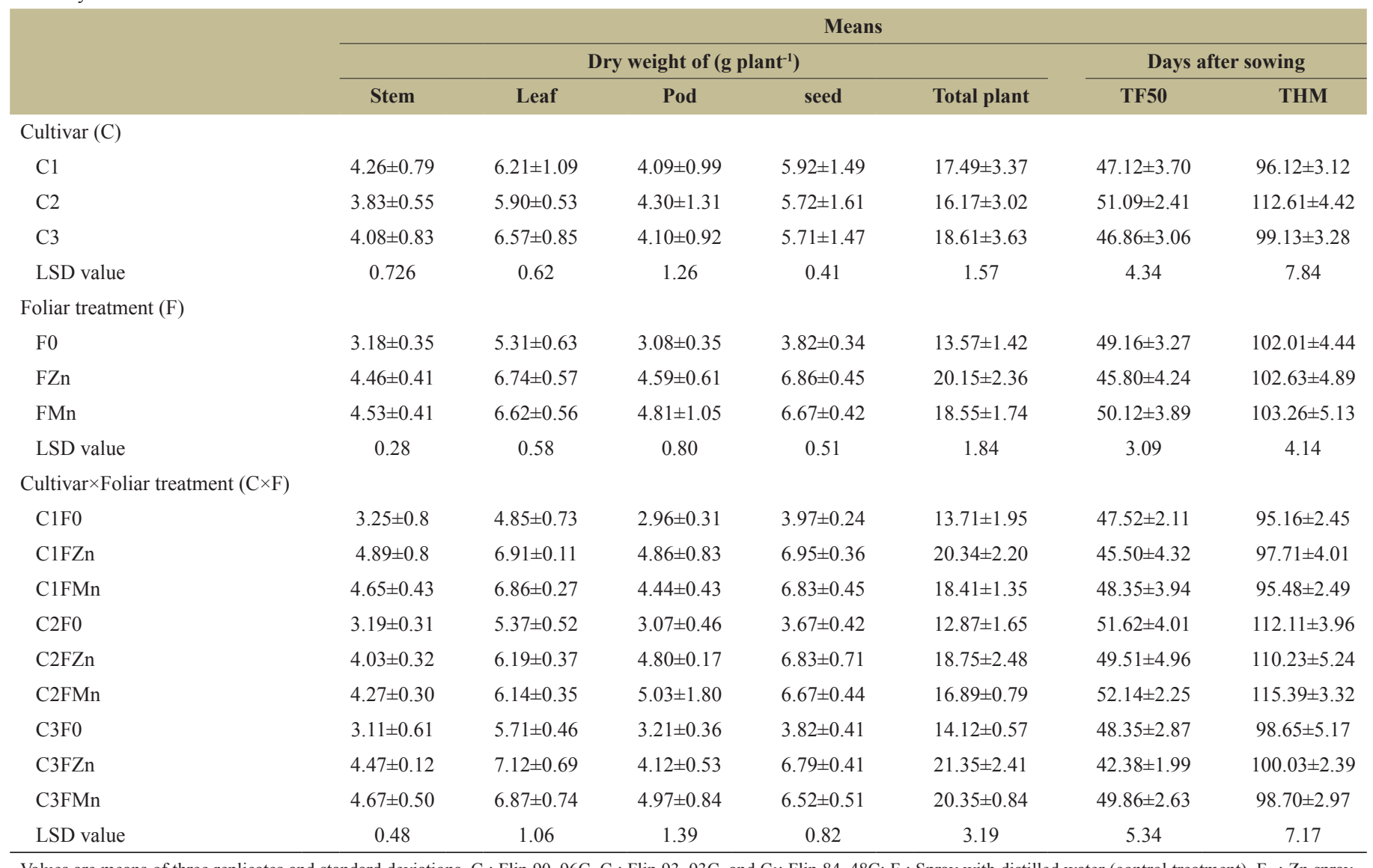

Values are means of three replicates and standard deviations. $\mathrm{C}_{1}$ : Flip 90-96C, $\mathrm{C}_{2}$ : Flip 93-93C, and $\mathrm{C}_{3}$ : Flip 84-48C; $\mathrm{F}_{0}$ : Spray with distilled water (control treatment), $\mathrm{F}_{\mathrm{Zn}}$ : Zn spray, and $\left(\mathrm{F}_{\mathrm{Mn}}\right) \mathrm{Mn}$ spray; TF50: Time to 50\% flowering, THM: Time to harvest maturity, Zn: Zinc, Mn: Manganese

results of the comparison of mean dry weight of stems, leaves, pods, seeds, and total plant length and from the time of emergence up to $50 \%$ flowering (TF50 and THM) are shown in Table 3. According to the results, although there was no significant difference between different cultivars in terms of dry weight of stems, leaves, pods, and seeds, the highest dry weight of stem (4.26 g) and seed (5.92 g) belonged to Flip 90-90C. In addition, the highest leaf dry weight $(6.57 \mathrm{~g})$ and dry weight of the whole plant $(18.61 \mathrm{~g})$ were recorded in Flip $84-48 \mathrm{C}$ cultivars. The lowest stem dry weight (3.83 g), leaf dry weight (5.90 g), and dry weight of the whole plant ( $16.17 \mathrm{~g})$ belonged to Flip 93-93C. Spraying of both $\mathrm{Zn}$ and $\mathrm{Mn}$ in comparison with the control treatments increased the dry weight of stems, leaves, pods, seeds, and total plant, but the effect of spray application on leaf dry weight increase $(6.74 \mathrm{~g})$, dry weight of seed (6.86 g), and dry weight of total plant (20.15 g) was effective, and the effect of Mn spraying increased the stem dry weight (4.53 g) and pod dry weight (PDW) (4.81 g). Previously, also Shaver et al., and Wang and Jin [17,18] reported a high correlation between the application of $\mathrm{Zn}$ fertilizers and their effect on plant growth. On the other hand, the reaction of different cultivars of chickpea was different from that of $\mathrm{Zn}$ and $\mathrm{Mn}$ foliar treatments [Table 3]. The highest dry weight of stem (4.89 g) and seed $(6.95 \mathrm{~g})$ belonged to Flip 90-96C, and the highest leaf dry weight (7.12 g) and total plant (21.35 g) belonged to Flip 84-48C and $\mathrm{Zn}$ spray application. In fact, in all three cultivars, Zn spraying had the greatest effect on the dry weight of stems, leaves, seeds, and total plant. According to Yang et al. [19], various crop varieties differ greatly in terms of the utilization of microelements. In this regard, researchers in the past also stated that there are many differences between different genotypes of a crop in terms of the response to a deficiency or excess amount of an element [20-22]. Based on the results obtained in this experiment, Mn sprays increased the PDW in Flip 93-93C more than other treatments (5.03 g). Izaguirre-Mayoral and Sinclair [23] reported that with increase in Mn concentration, leaf dry weight, and shoot dry weight increased, and this increase is dependent on the genetic characteristics of the plant. The results of correlation analysis between traits [Table 2] revealed that there was a positive and significant correlation between dry weight of grain with stem dry weight $\left(r=0.84^{* *}\right)$, dry weight of pod $\left(r=0.76^{* *}\right)$, and dry weight of whole plant $(r=0.80 * *)$.

\subsection{Effect of Cultivar and Foliar Treatments on Yield and Its Components}

The results of analysis of variance of yield and yield components of chickpea under the influence of variety and different treatments of $\mathrm{Zn}$ and Mn spraying are shown in Table 4. According to the results, there was a significant difference between cultivars in terms of plant height and 100 -seed weight at $1 \%$ level $(P<0.01)$ and in terms of number of branches and harvest index at $5 \%$ level $(P<0.05)$. In contrast, there was no significant difference between number of pods per plant, number of seeds per plant, grain yield, and biological yield. On the contrary, spray application was not only effective on plant height but also other traits were affected by spray treatments, as such; the effect of spraying on the number of branches at $5 \%$ level 
and other traits at $1 \%$ level was significant. Apart from the weight of 100 seeds of chickpea which was affected by interaction effects of cultivars and spraying at $5 \%$ level, the interaction effect of these two factors did not have a significant effect on the other studied traits [Table 4]. Research by Thalooth et al., and Hu et al. [24,25] showed that $\mathrm{Zn}$ fertilization has little or no effect on plant height, but $\mathrm{Mn}$ spraying can increase plant height in some plants. On the other hand, according to Babaeian et al. [26], although the effect of $\mathrm{Zn}$ and Mn fertilization was not statistically significant on sunflower seed yield, simultaneous consumption of these two elements led to a slight increase in yield of sunflower. However, Yousefi [27] stated that $\mathrm{Zn}$ and $\mathrm{Mn}$ application can significantly increase the crop yield. The results of comparison of mean of cultivars and different treatments of foliar application on yield and yield components of chickpea have been shown in Table 5. According to the results, the highest plant height $(43.51 \mathrm{~cm})$ and number of seeds per plant (21.01) were in Flip 90-90C and the highest number of branches (3.65), number of pods per plant (17.84), grain yield (110.58 $\left.\mathrm{g} \mathrm{m}^{-2}\right)$, and biological yield $\left(212.03 \mathrm{~g} \mathrm{~m}^{-2}\right)$ were recorded in the Flip $84-48 \mathrm{C}$ cultivar. Furthermore, Flip 9-93C had the highest grain weight (36.60 g) and harvest index (49.13\%). On the contrary, compared to other spray treatments, Zn spraying increased plant height $(42.53 \mathrm{~cm})$, number of pods per plant (19.29), number of seeds per plant (23.02), 100seed weight $(34.89 \mathrm{~g})$, grain yield $\left(11640 \mathrm{~g} \mathrm{~m}^{-2}\right)$, and biological yield (222.37 $\left.\mathrm{g} \mathrm{m}^{-2}\right)$ in chickpea. Mansur et al. [28] reported that Zn consumption will increase the grain yield by increasing the number of seeds per plant and seed weight. Numerous research studies have highlighted the role and importance of $\mathrm{Zn}$ in enhancing the yield and production of crops [29-31]. Mn spraying increased the number of branches (3.56) and harvest index (51.75\%) in chickpea. The results

Table 3: The effect of $\mathrm{Zn}$ and $\mathrm{Mn}$ sulfate on [Zn]leaf and [Zn]seed and [Mn]leaf and [Mn]seed

\begin{tabular}{|c|c|c|c|c|}
\hline & \multicolumn{4}{|c|}{ Means } \\
\hline & \multicolumn{4}{|c|}{ Concentration $\left(\mathrm{mg} \mathrm{g}^{-1}\right)$} \\
\hline & [Zn]leaf & {$[\mathrm{Zn}]$ seed } & [Mn]leaf & [Mn]seed \\
\hline $\mathrm{C} 1$ & $26.79 \pm 7.38$ & $44.53 \pm 8.45$ & $21.82 \pm 7.13$ & $28.92 \pm 5.22$ \\
\hline $\mathrm{C} 2$ & $29.86 \pm 8.47$ & $45.66 \pm 9.79$ & $22.56 \pm 9.86$ & $30.90 \pm 7.46$ \\
\hline $\mathrm{C} 3$ & $26.65 \pm 6.70$ & $48.10 \pm 9.68$ & $24.19 \pm 8.91$ & $26.95 \pm 5.23$ \\
\hline \multicolumn{5}{|c|}{ Foliar treatment $(\mathrm{F})$} \\
\hline F0 & $16.34 \pm 1.85$ & $28.65 \pm 4.14$ & $11.90 \pm 1.75$ & $21.59 \pm 2.91$ \\
\hline FZn & $42.75 \pm 5.06$ & $72.21 \pm 5.67$ & $17.58 \pm 3.84$ & $24.54 \pm 3.39$ \\
\hline FMn & $24.22 \pm 2.41$ & $37.43 \pm 3.37$ & $39.09 \pm 5.89$ & $40.65 \pm 3.73$ \\
\hline C1FMn & $22.79 \pm 2.82$ & $39.73 \pm 4.01$ & $35.89 \pm \pm 4.74$ & $38.61 \pm 4.00$ \\
\hline $\mathrm{C} 2 \mathrm{~F} 0$ & $15.73 \pm 2.21$ & $27.20 \pm 1.98$ & $13.34 \pm 0.35$ & $23.72 \pm 1.94$ \\
\hline $\mathrm{C} 2 \mathrm{FZn}$ & $48.25 \pm 4.96$ & $75.31 \pm 7.35$ & $15.61 \pm 4.12$ & $25.81 \pm 1.67$ \\
\hline $\mathrm{C} 2 \mathrm{FMn}$ & $15.61 \pm 2.58$ & $34.48 \pm 1.77$ & $38.72 \pm 6.34$ & $43.17 \pm 3.21$ \\
\hline $\mathrm{C} 3 \mathrm{~F} 0$ & $16.97 \pm 1.05$ & $32.49 \pm 4.84$ & $10.18 \pm 1.55$ & $19.35 \pm 2.62$ \\
\hline $\mathrm{C} 3 \mathrm{FZn}$ & $38.73 \pm 2.22$ & $73.72 \pm 4.71$ & $19.73 \pm 4.90$ & $21.33 \pm 1.75$ \\
\hline C3FMn & $24.26 \pm 2.61$ & $38.08 \pm 2.14$ & $42.65 \pm 5.31$ & $40.16 \pm 3.65$ \\
\hline LSD value & 5.00 & 6.51 & 6.28 & 6.41 \\
\hline
\end{tabular}

Values are means of three replicates and standard deviations. $C_{1}$ : Flip 90-96C, $C_{2}$ : Flip 93-93C, and $\mathrm{C}_{3}$ : Flip 84-48C; F : Spray with distilled water (control treatment), FZn: Zn spray, and (FMn) Mn spray; [Zn]leaf: Leaf Zn concentration, [Zn]seed: Seed Zn concentration, [Mn]leaf: Leaf Mn concentration, [Mn]seed: Seed Mn concentration, Zn: Zinc, Mn: Manganese

Table 4: Analysis of variance for the impact of $\mathrm{Zn}$ and Mn sulfate on [Zn]leaf and seed, [Mn]leaf and seed, and seed protein content

\begin{tabular}{|c|c|c|c|c|c|c|}
\hline \multirow[t]{3}{*}{ SOV } & \multirow[t]{3}{*}{ df } & \multicolumn{5}{|c|}{ Ms } \\
\hline & & \multicolumn{4}{|c|}{ Concentration } & \multirow[t]{2}{*}{ Seed protein content } \\
\hline & & [Zn]leaf & {$[\mathrm{Zn}]$ seed } & [Mn]leaf & [Mn]seed & \\
\hline Replication & 2 & 0.906 & 18.576 & 9.467 & 1.664 & 0.603 \\
\hline Cultivar(C) & 2 & $29.613^{\mathrm{ns}}$ & $29.874^{\mathrm{ns}}$ & $13.170 \mathrm{~ns}$ & $35.165^{* *}$ & $14.011^{* *}$ \\
\hline Error a & 4 & 5.586 & 19.389 & 35.646 & 0.634 & 0.425 \\
\hline Foliar treatment $(\mathrm{F})$ & 2 & $1655.357 * *$ & $4777.536 * *$ & $1851.041 * *$ & $947.277 * *$ & $13.159 * *$ \\
\hline $\begin{array}{l}\text { Cultivar } \times \text { Foliar treatment } \\
(\mathrm{C} \times \mathrm{F})\end{array}$ & 4 & $25.176^{\mathrm{ns}}$ & $37.61^{\mathrm{ns}}$ & $20.931 \mathrm{~ns}$ & $9.386^{\mathrm{ns}}$ & $0.950^{\mathrm{ns}}$ \\
\hline Error b & 12 & 7.912 & 13.377 & 12.487 & 13.186 & 1.168 \\
\hline Coefficient of variation ( $\%)$ & - & 10.13 & 7.93 & 15.46 & 12.55 & 5.37 \\
\hline
\end{tabular}

Ns and **: Non-significant and significant at 1\% levels of probability, respectively, [Zn]leaf: Leaf Zn concentration, [Zn]seed: Seed Zn concentration, [Mn]leaf: Leaf Mn concentration, [Mn]seed: Seed Mn concentration, SOV: Source of variation, Zn: Zinc, Mn: Manganese 
of the comparison of the means on the interaction between cultivars and spraying treatments [Table 5] show that $\mathrm{Zn}$ spray application had the highest effect on number of pods per plant (20.61), grain yield $\left(125.11 \mathrm{~g} \mathrm{~m}^{-2}\right)$, and biological yield $\left(230.65 \mathrm{~g} \mathrm{~m}^{-2}\right)$ in Flip 84-48C, while $\mathrm{Zn}$ spray application had the highest effect on plant height $(44.71 \mathrm{~cm})$ and number of seeds per plant (24.07) in Flip 9096C cultivar. The results of Heitholt et al. [32] indicated that with $\mathrm{Zn}$ consumption, the number of seeds per plant increased by about twice compared to control treatment. The highest harvest index belonged to Mn spraying in Flip 84-48C cultivar. De Varennes and Goss [33] stated that if the consumption of nutrients causes a balance between nutrients in soil and plant, it can have a positive effect on the growth and production of crops. On the other hand, researchers have linked the decline in growth and crops production with the competition of $\mathrm{Zn}$ with other elements in absorption [3], the existence of known and/or unknown interaction between $\mathrm{Zn}$ and other elements [34], the activity of certain enzymes that affect plant metabolism [30], decrease in plant photosynthesis [35,36], and a decrease in chlorophyll synthesis [34]. Research by Liagat et al. [37] demonstrated that $\mathrm{Zn}$ application could increase grain yield in cotton. They stated that the plants grown in calcareous soils are usually faced with $\mathrm{Zn}$ deficiency and supplying the plant nutrition requirements will not only increase the quality and quantity of crop products but also increase the level of health in the community. The effect of $\mathrm{Zn}$ on the increased biological yield of chickpea in Balai et al. [38] experiment has also been emphasized. The results of Pearson correlation [Table 2] showed that there was a positive and significant correlation between the number of seeds per plant with grain yield $\left(r=0.85^{* *}\right)$ and number of pods per plant $\left(r=0.70^{* *}\right)$. Furthermore, there was a positive and significant correlation between 100 -seed weight and harvest index at $1 \%$ level $\left(r=0.64^{* *}\right)$.

\subsection{Effect of Cultivar and Foliar Treatments on [Zn]Leaf and Seed, [Mn]Leaf and Seed, and Seed Protein Content}

The results of analysis of variance of $\mathrm{Zn}$ and $\mathrm{Mn}$ concentrations in leaves and seeds as well as protein content in chickpea seed are shown in Table 6 . According to the results, there was no significant difference between different cultivars in terms of $\mathrm{Zn}$ concentration in leaf and seed and Mn concentrations in chickpea leaves, while Mn concentration and protein content in chickpea grain were significantly different at $1 \%$ level $(P<0.01)$. In contrast, different spraying treatments caused a significant difference at $1 \%$ level in all traits studied in Table 6. The interaction effect of cultivar with $\mathrm{Zn}$ and $\mathrm{Mn}$ fertilizations $(\mathrm{F} \times \mathrm{C})$ was not affected by $\mathrm{Zn}$ concentration in leaves and seeds, Mn concentration in leaves and seeds, and protein content of chickpea seed. The results of the comparison of means [Table 7] show that although the $\mathrm{Zn}$ concentration in the leaves and seed of chickpea cultivars had no significant difference, the highest $\mathrm{Zn}$ concentrations in leaves and seeds were observed in Flip 9393C (129.86 mg/g) and Flip 84-48C (40.10 mg/g), respectively. In addition, the highest concentrations of $\mathrm{Mn}$ in leaves and seeds were recorded in Flip 84-48C (24.19 mg/g) and Flip 93-93C (30.90 mg/g), respectively. As expected, the use of $\mathrm{Zn}$ and $\mathrm{Mn}$ elements led to a sharp increase in the concentration of these elements in the leaves and seeds of the plant so that the highest $\mathrm{Zn}$ concentrations in the leaf $(42.75 \mathrm{mg} / \mathrm{g})$ and grain $(72.21 \mathrm{mg} / \mathrm{g})$ of chickpea were observed

Table 5: The effect of $\mathrm{Zn}$ and $\mathrm{Mn}$ sulfate on yield and yield components of chickpea

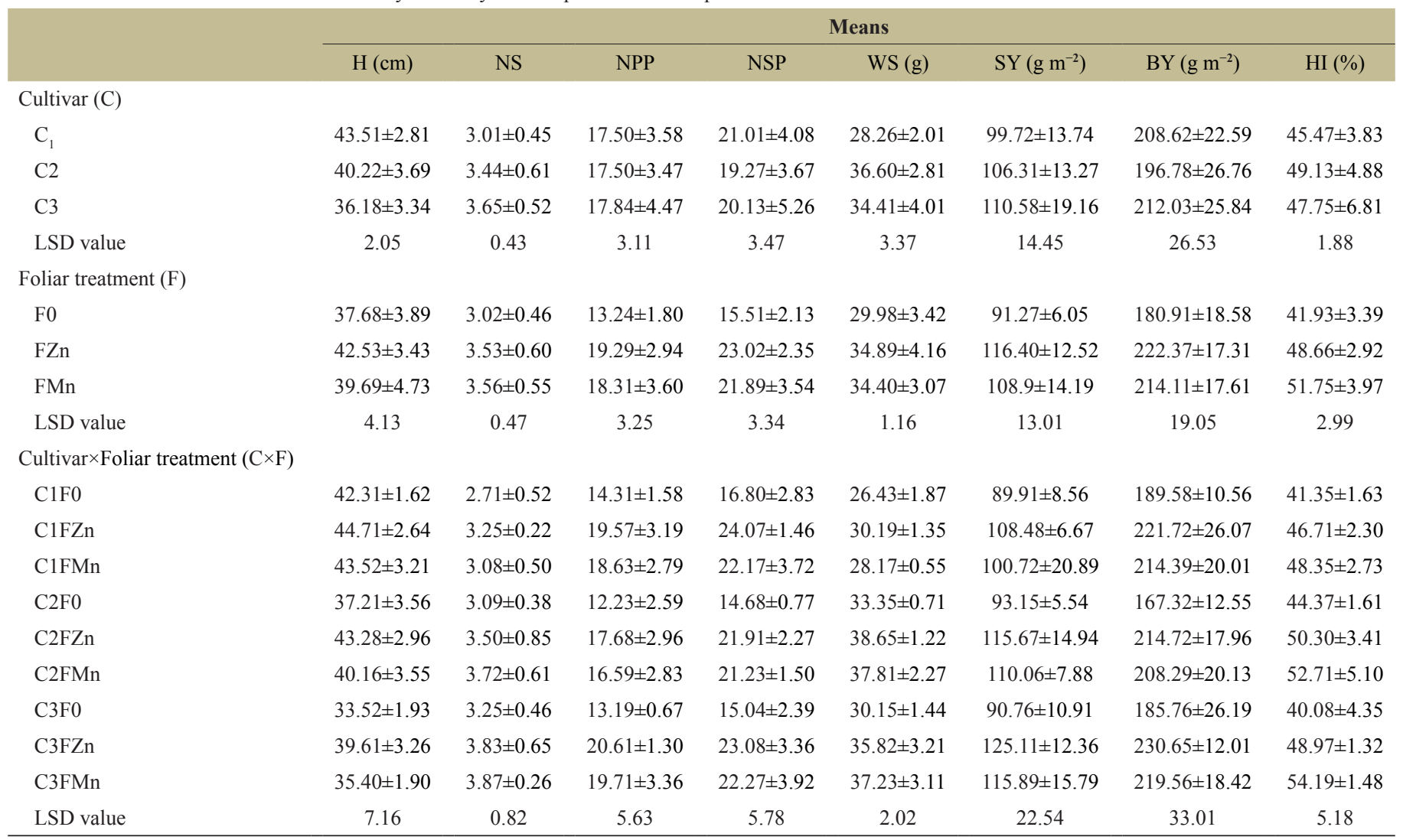

Values are means of three replicates and standard deviations. $\mathrm{C}_{1}$ : Flip 90-96C, $\mathrm{C}_{2}$ : Flip 93-93C, and $\mathrm{C}_{3}$ : Flip 84-48C; $\mathrm{F}_{0}$ : Spray with distilled water (control treatment), $\mathrm{F}_{\mathrm{Zn}}$ : Zn spray, and $\left(\mathrm{F}_{\mathrm{Mn}}\right) \mathrm{Mn}$ spray; H: Plant height, NS: Number of subbranch, NPP: Number of pod per plant, WS: 100-seed weight, SY: Seed yield, BY: Biological yield, and HI: Harvest index, Zn: Zinc, Mn: Manganese 


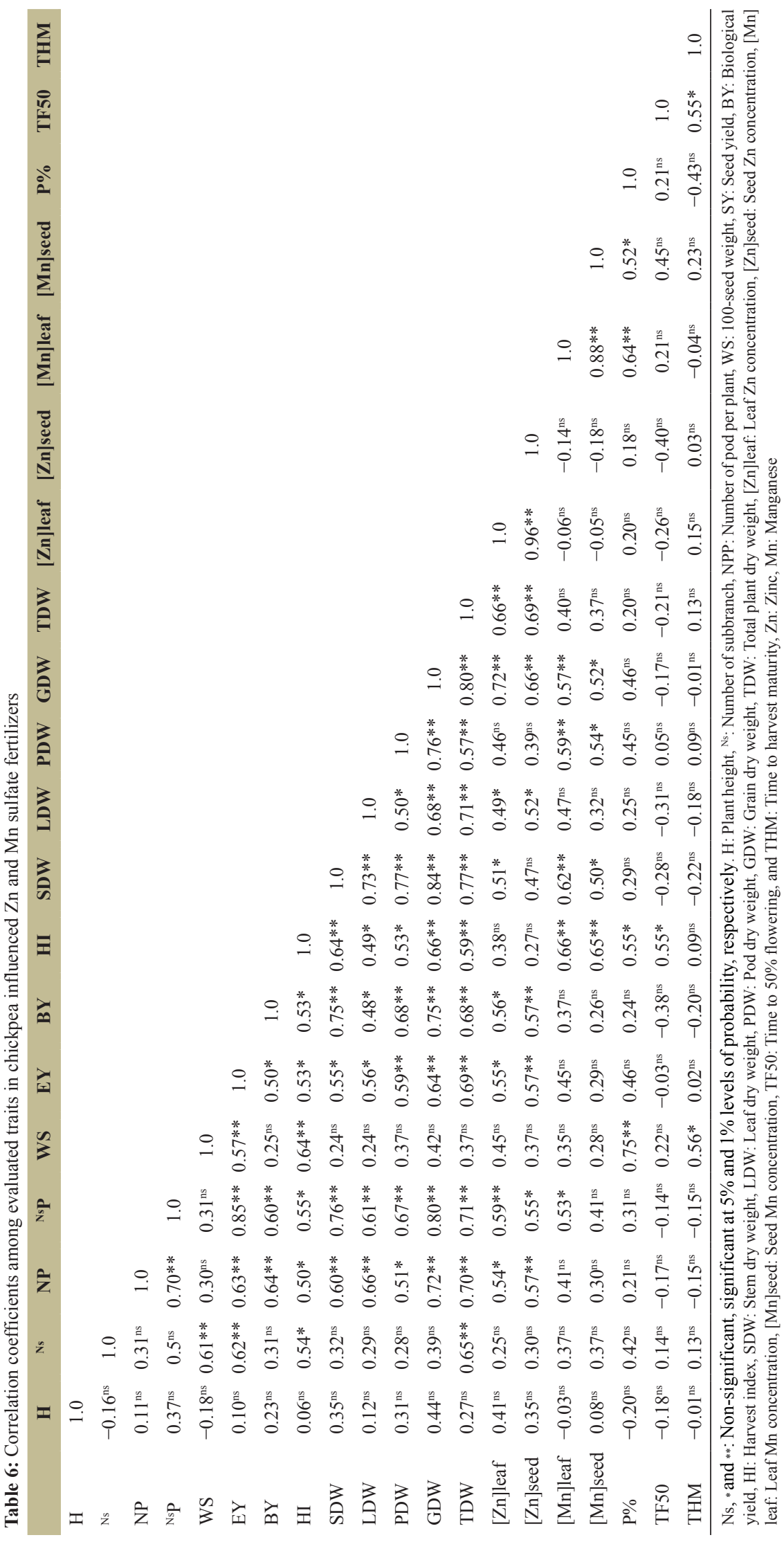


Table 7: Analysis of variance for the impact of $\mathrm{Zn}$ and $\mathrm{Mn}$ sulfate fertilization on yield and yield components of chickpea

\begin{tabular}{|c|c|c|c|c|c|c|c|c|c|}
\hline \multirow[t]{2}{*}{ SOV } & \multirow[t]{2}{*}{ df } & \multicolumn{8}{|c|}{ Ms } \\
\hline & & $\mathbf{H}$ & NS & NPP & NSP & WS & SY & BY & HI \\
\hline Replication & 2 & 1.199 & 1.018 & 10.677 & 4.549 & 13.819 & 99.818 & 218.992 & 36.441 \\
\hline Error a & 4 & 2.461 & 0.106 & 5.646 & 7.041 & 6.645 & 121.968 & 410.814 & 2.057 \\
\hline Foliar treatment & 2 & $53.483 \mathrm{~ns}$ & $0.831^{*}$ & $94.720 * *$ & $147.740 * *$ & $65.906 * *$ & $1501.200^{* *}$ & $4331.940 * *$ & $226.757 * *$ \\
\hline Coefficient of variation (\%) & - & 10.07 & 13.65 & 18.69 & 16.14 & 4.42 & 12.00 & 9.01 & 6.14 \\
\hline
\end{tabular}

ns, * and **: Non-significant, significant at $5 \%$ and $1 \%$ levels of probability, respectively, H: Plant height, NS: Number of subbranch, NPP: Number of pod per plant, WS: 100 -seed weight, SY: Seed yield, BY: Biological yield, HI: Harvest index, SOV: Source of variation, Zn: Zinc, Mn: Manganese

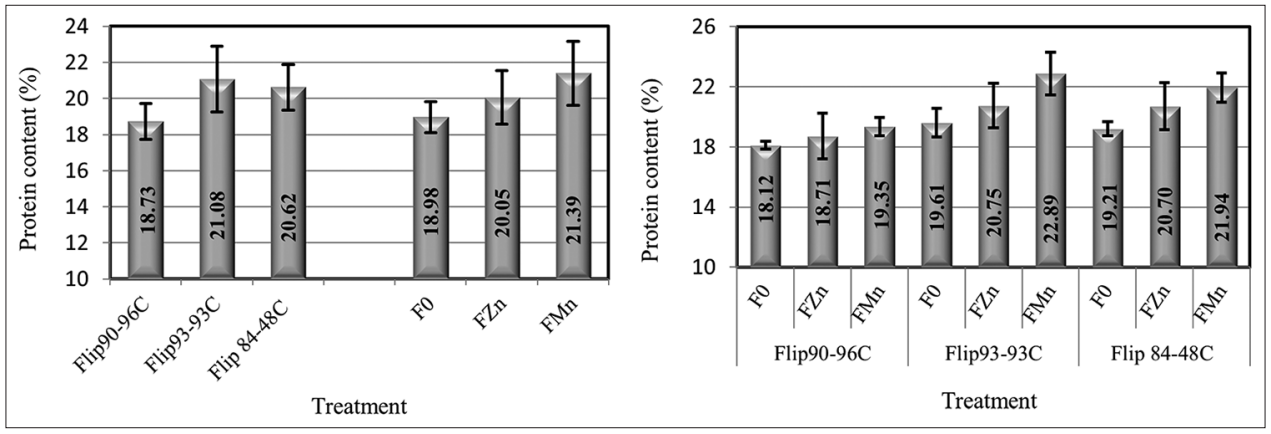

Figure 1: The effect of zinc and manganese sulfate on seed protein content of chickpea

in $\mathrm{Zn}$ spraying, and the highest concentration of $\mathrm{Mn}$ in the leaves (39.09 mg/g) and grain (40.65 mg/g) was recorded in Mn spraying. Balai and Hidoto [38,39] studies showed that with $\mathrm{Zn}$ application, $\mathrm{Zn}$ concentrations in seeds and shoots of chickpea were increased. Interaction effects of cultivars and $\mathrm{Zn}$ and Mn spraying on $\mathrm{Zn}$ and $\mathrm{Mn}$ concentration in chickpea leaves and stems were not statistically significant, but according to Table 7, the highest $\mathrm{Zn}$ concentrations in leaf $(48.25 \mathrm{mg} / \mathrm{g})$ and grain $(75.31 \mathrm{mg} / \mathrm{g})$ in Flip $93-93 \mathrm{C}$ cultivar and the highest $\mathrm{Mn}$ concentration in leaf $(42.65 \mathrm{mg} / \mathrm{g})$ and seed $(40.16 \mathrm{mg} / \mathrm{g})$ were observed in Flip $84-48 \mathrm{C}$ and Flip 93-93C cultivars, respectively. Existence of sufficient amounts of nutrients in crop seed is one of the important factors in increasing the quality of crop production, which depends on the process of absorption and remobilization from other parts of the plant to the seeds [40,41]. There is a lot of difference between elements in terms of remobilization process so that some elements have little ability to retransfer from other organs to the grain [20]. In our experiment with $\mathrm{Zn}$ fertilization, Mn concentration in leaf and seed in all of the cultivars was increased. Furthermore, similar results were obtained with Mn spraying. Zn concentrations increased in leaves and grains by Mn spraying [Table 7]. There was a positive and significant correlation at $1 \%$ level between $\mathrm{Zn}$ concentration in leaf with dry weight of grain $(r=0.72 * *)$ and dry weight of total plant $\left(r=0.66^{* *}\right)$. Furthermore, there was a positive and significant correlation between $\mathrm{Zn}$ concentration in grain with dry weight of grain $\left(r=0.66^{* *}\right)$ and dry weight of total plant $\left(r=0.69^{* *}\right)$ [Table 2]. The highest and lowest protein content in chickpea seed were measured in Flip 93-93C (21.08\%) and Flip 90-96C (18.73\%), respectively [Figure 1]. On the other hand, Mn spraying had the greatest effect on the increase in protein content of chickpea seed compared to other treatments so that Mn spraying increased the protein content of chickpea seeds by $12.69 \%$ compared to the control treatment (non-spraying). Research conducted by Balai et al., and Choudhary et al. [38,42] showed that $\mathrm{Zn}$ intake could increase protein in chickpea seeds. They stated that $\mathrm{Zn}$ consumption as compared to non-intake treatment could increase the protein content of chickpea seed. According to Seguin and Zheng [43], the balance nutrition of the plant and the optimal use of chemical fertilizers can affect the amount of oil and protein in the crops. As can be shown in Figure 1, Mn spray had a great influence on the protein content of the Flip 93-93C variety $(22.89 \%)$. In all cultivars, the least amount of protein belonged to the check treatment. In this experiment, increase in the amount of protein resulting from the $\mathrm{Zn}$ spraying in all three varieties was very low.

\section{CONCLUSION}

The results of this experiment showed that $\mathrm{Zn}$ and $\mathrm{Mn}$ elements increased the dry weight of the pod, and there was no significant difference between these two elements. Among cultivars, the Flip 84-48C had more ability to transfer $\mathrm{Zn}$ from leaves to seeds. In this study, synergistic effects between $\mathrm{Zn}$ and $\mathrm{Mn}$ were observed so that the application of each of these elements increased the concentration of others in chickpea leaves and seeds. Mn application increased $\mathrm{Zn}$ concentration in leaves and chickpea seed. In fact, $\mathrm{Mn}$ improves the storage of $\mathrm{Zn}$ in the leaf and transfers it to chickpea seeds.

\section{ACKNOWLEDGMENTS}

The author acknowledges the financial support of the Islamic Azad University of Kermanshah which kindly provided both laboratory facilities and a grant. 
Soheil Kobraee: Effect of foliar fertilization with zinc and manganese sulfate on yield, dry matter accumulation, and zinc and manganese contents in leaf and seed of chickpea (Cicer arietinum) 2019;7(03):20-28

\section{REFERENCES}

1. Gangwar S, Dubey M. Effect on N and P uptake by chickpea (Cicer arietinum L.) as influenced by micronutrients and bio fertilizers. Legume Res 2012;35:164-8.

2. Kaur S, Kaur S, Gupta AK, Kaur J. Physiochemical and nutritional attributes of raw and soaked seeds of chickpea (Cicer arietinum L.) genotypes. Legume Res 2016;39:359-69.

3. Dragičević V, Kratovalieva S, Dimov Z, Babić V, Kresović B, Kravić N. Potential bioavailability of calcium, magnesium, iron, manganese and zinc from seeds of different chickpea and peanut landraces. J Elem 2018;23:273-85.

4. Food and Agriculture Organization. Area Harvested and Production in FAO; 2016. Available from: http://www.faostat. [Last retrieved on2018 Feb 21].

5. Ducic T, dolle A. Transport and detoxification of manganese and copper in plants. Braz J Plant physiol 2005;17:103-12.

6. Rosas A, Rengel Z, Mora ML. Manganese supply and $\mathrm{pH}$ influence growth, carboxylate exudation and peroxidase activity of ryegrass and white clover. J Plant Nutr 2007;30:253-70.

7. Murillo-Amador B, Jones HG, Kaya C. Effects of foliar application calcium nitrate on growth and physiological attributes of cowpea (Vigna unguiculaa L. Walp.) grown under salt stress. Environ Exp Bot 2006;58:188-96.

8. Fageria NK, Filho MP, Moreira A, Guimaraes CM. Foliar fertilization of crop plants. J Plant Nutr 2009;32:1044-64.

9. Sarkar D, Mandal B, Kundu MC. Increasing use efficiency of boron fertilizers by rescheduling the time and methods of application for crops in India. Plant Soil 2007;301:77-85.

10. Heidarian AR, Kord H, Mosafavi K, Lak AP, Mashhadi FA. Investigation $\mathrm{Fe}$ and $\mathrm{Zn}$ foliar application on yield and its components of soybean (Glycine $\max$ L.) at different growth stages. J Agric Biotech Sustain Dev 2011;3:189-97.

11. Narimani H, Rahimi MM, Ahmadikhah A, Vaezi B. Study on the effects of foliar spray of micronutrient on yield and yield components of durum wheat. Arch Appl Sci Res 2010;2:168-76.

12. Dayanand S, Mehta M, Verma RK. Seed yield and economics of chickpea (Cicer arietinum) as influenced by foliar application of agrochemicals. Indian J Agric Res 2013;47:359-62.

13. Kacar B. Plant nutrition practice guide. Practice Guides. Ankara, Turkey: Ankara University, Agricultural Faculty, Publication; 1984. p. $900,214$.

14. Latimer GW. Official Methods of Analysis of AOAC International. Gaithersburg, MD, USA: AOAC International; 2016.

15. Sabaghnia N, Janmohammadi M. Analysis of the impact of nanozinc, nano-iron, and nano-manganese fertilizers on chickpea under rain-fed conditions, Ann Univ Mariae Curie Sklodowska Biol 2015;2:43-55.

16. Janmohammadi M, Sabaghnia N, Seifi A, Pasandi M. The impacts of nano-structured nutrients on chickpea performance under supplemental irrigation. Acta Univ Agric Silviculturae Mendelianae Brunensis 2017;65:859-70.

17. Shaver TM, Westfall DG, Ronaghi M. Zinc fertilizer solubility and its effects on zinc bioavailability over time. J Plant Nutr 2007;30:123-33.

18. Wang H, Jin JY. Effects of zinc deficiency and drought on plant growth and metabolism of reactive oxygen species in maize (Zea mays L.). Agric Sci China 2007;6:988-95.

19. Yang XE, Ye ZQ, Shi CH, Zhu ML, Graham RD. Genotypic differences in concentrations of iron, manganese, copper, and zinc in polished rice grains. J Plant Nutr 1998;21:1453-62.

20. Moraghan TJ, Padilla J, Etchevers JD, Grafton K, Acosta-Gallegos JA. Iron accumulation in seed of common bean. Plant Soil 2002;246:175-83.

21. Khudsar T, Arshi A, Siddiqi TO, Mahmooduzzafar M, Iqbal M.
Zinc-induced changes in growth characters, foliar properties, and zn-accumulation capacity of pigeon pea at different stages of plant growth. J Plant Nutr 2008;31:281-306.

22. Fageria NK. The Use of Nutrients in Crop Plants. Boca Raton, FL: CRC Press, Taylor and Francis Group; 2009.

23. Izaguirre-Mayoral ML, Sinclair T. Irradiance regulates genotypespecific responses of rhizobium nodulated soybean to increasing iron and two manganese concentrations in solution culture. J Plant Physiol 2009;166:807-18.

24. Thalooth AT, Tawfik MM, Mohamed HM. A comparative study on the effect of foliar application of zinc, potassium and magnesium on growth, yield and some chemical constituents of mungbean plants grown under water stress conditions. World J Agric Sci 2006;2:37-46.

25. $\mathrm{Hu} \mathrm{Y,} \mathrm{Burucs} \mathrm{Z}$, Schmidhalter U. Effect of foliar fertilization application on the growth and mineral nutrient content of maize seedlings under drought and salinity. Soil Sci Plant Nutr 2008;54:133-41.

26. Babaeian M, Tavassoli A, Ghanbari A, Esmaeilian Y, Fahimifard M. Effects of foliar micronutrient application on osmotic adjustments, grain yield and yield components in sunflower (Alstar cultivar) under water stress at three stages. Afr J Agric Res 2011;6:1204-8.

27. Yousefi M. Impact of $\mathrm{Zn}$ and $\mathrm{Mn}$ foliar application on yield of pumpkin (Cucurbita Pepo L.) under two irrigation regimes. Int J Agric Res Rev 2012;2:102-7.

28. Mansur CD, Hundekar AR, Kubsad VG, Gowda DS, Honshal S. Response of soybean to micronutrients. Ann Agric Sci Cario 1995;11:55-7.

29. Ejaz M, Waqas R, Butt M, Rehman SU, Manan A. Role of macronutrients and micro-nutrients in enhancing the quality of tomato. Int J Agron Vet Med Sci 2011;5:401-4.

30. Gurmani AR, Ud-Din J, Khan SU, Andaleep R, Waseem K, Khan A, et al. Soil application of zinc improves growth and yield of tomato. Int J Agric Biol 2012;14:91-6.

31. SHinde P, Doddagoudar SR, Vasudevan SN. Influence of seed polymer coating with micronutrients and foliar spray on seed yield of chickpea (Cicer arietinum L.). Legume Res 2017;40:704-9.

32. Heitholt JJ, Sloan JJ, Mackown CT. Copper, manganese, and zinc fertilization effects on growth of soybean on a calcareous soil. J Plant Nutr 2002;25:1727-40.

33. De Varennes A, Goss MJ. The tripartite symbiosis between legumes, rhizobia and indigenous mycorrhizal fungi is more efficient in undisturbed soil. Soil Biol Biochem 2007;39:2603-7.

34. Kaya C, Higgs D. Response of tomato (Lycopersicon esculentum L.) cultivars to foliar application of zinc when grown in sand culture at low zinc. Sci Hortic 2002;93:53-64.

35. Bonnet M, Camares O, Veisseire P. Effects of zinc and influence of Acremonium lolii on growth parameters, chlorophyll a fluorescence and antioxidant enzyme activities of ryegrass (Lolium perenne L. cv Apolle). J Exp Bot 2000;51:945-53.

36. Khudsar T, Mahmooduzzafar M, Iqbal M, Sairam RK. Zinc-induced changes in morpho-physiological and biochemical parameters in Artemisia annua. Biol Plant 2004;48:255-60.

37. Liagat A, Mushtaq A, Qamar M. Effect of application of zinc and boron on seed cotton yield and economics in cotton-wheat cropping pattern. J Agric Res 2011;49:173-80.

38. Balai K, Jajoria M, Verma R, Deewan P, Bairwa SK. Nutrient content, uptake, quality of chickpea and fertility status of soil as influenced by fertilization of phosphorus and zinc. J Pharmacogn Phytochem 2017;6:392-8

39. Hidoto L, Worku W, Mohammed H, Taran B. Effects of zinc application strategy on zinc content and productivity of chickpea grown under zinc deficient soils. J Soil Sci Plant Nutr 2017;17:112-26.

40. Hacisalihoglu G, Ozturk L, Cakmak IR, Welch M, Kochian L. Genotypic variation in common bean in response to zinc deficiency 
in calcareous soil. Plant Soil 2004;259:71-83.

41. Waters BM, Sankaran RP. Moving micronutrients from the soil to the seeds: Genes and physiological processes from a bio fortification perspective. Plant Sci 2011;180:562-74.

42. Choudhary GL, Rana KS, Bana RS, Prajapat K. Moisture conservation and zinc fertilization impacts on quality, profitability and moisture use indices of chickpea (Cicer arietinum L.) under limited moisture conditions. Legume Res 2016;39:734-40.

43. Seguin P, Zheng W. Potassium, phosphorous, sulfur and boron fertilization effects on soybean isoflavone content and other seed characteristics. J Plant Nutr 2006;29:681-98.

How to cite this article:

Soheil Kobraee. Effect of foliar fertilization with zinc and manganese

sulfate on yield, dry matter accumulation, and zinc and manganese contents

in leaf and seed of chickpea (Cicer arietinum). J App Biol Biotech.

2019;7(03):20-28. Doi: 10.7324/JABB.2019.70305 